\title{
ADAPTATION PROCESSES IN AGRICULTURE VS. MARKET REQUIREMENTS AND SUSTAINABLE DEVELOPMENT PRINCIPLES
}

\author{
Wojciech Ziętara ${ }^{\bowtie}$ \\ Institute of Agricultural and Food Economics - National Research Institute, Poland
}

\begin{abstract}
This paper presents changes in the structure of the national economy in Poland, mainly in the post-war period, manifested through a dramatic decline in the share of agriculture in the Gross Domestic Product (GDP) and employment and a decrease in household food expenses. However, this does not represent a decline in the importance of agriculture, which is the first link in the food economy. As a result of technical and biological progress, the level of intensity of agricultural production and land productivity increased, which made it possible to satisfy food needs. Given that, attention started to be paid to other agricultural functions related to the protection of the environment, including landscape. The economic objectives of farmers striving to further increase the level of production intensity and farm area (market and production scale) started competing with environmental protection objectives. The purpose of this paper is to present agricultural production systems that differ in the degree of accounting for measures related to environmental protection. To this end, the following farming systems were evaluated: conventional, organic, integrated and precision farming systems, taking into account the principles of the Common Agricultural Policy. The systems assume a holistic approach to the organization of farms and the commitment to circular economy. These expectations are met to the greatest extent by the organic farming system. However, this system will not dominate due to existing limitations (in knowledge and markets). It is the integrated farming system that should prevail, as it makes it possible to the greatest extent to meet the farmers' economic and social objectives while addressing the environmental protection objectives. Also, the fulfillment of environmental objectives by farmers gives legitimacy to supporting their activities from the state budget.
\end{abstract}

Keywords: agriculture, farms, farming systems

\section{INTRODUCTION}

The hitherto used method of assessing the place and role of agriculture in the national economy (by determining its contribution to the Gross Domestic Product and the share of people employed in agriculture in the total number of employees) has lost its importance. In Poland, in the post-war period (in 1950), the share of agriculture in GDP was about 30\% (Rocznik Statystyczny, 1961), and the share of people employed in agriculture in the total number of employees was $55.6 \%$ (Jezierski and Leszczyńska, 2003). These ratios were typical of an agricultural country. The industrialization program implemented in Poland in the post-war period, as well as the development of other sectors, including services, led to a decline in the share of agriculture in GDP to $2.6 \%$ in 2015. That year, the share of people employed in agriculture in the total number of employees decreased to $11.5 \%$. In the developed EU countries (EU-15), in recent years, the share of agriculture in GDP varied in the range of $0.6-1.8 \%$ while the share of people employed in agriculture in the total number of employees fluctuated between $1.1 \%$ and $2.8 \%$ (Statistisches Jahrbuch..., 2016). The share of food in total household expenses is another indicator of the importance of agriculture.

$\bowtie$ Prof. PhD hab. Wojciech Ziętara, Institute of Agricultural and Food Economics - National Research Institute, Świętokrzyska 20 St., 00-002 Warszawa, Poland, e-mail: Wojciech.Zietara@ierigz.waw.pl; https://orcid.org/0000-0002-3182-522X 
Ziętara, W. (2018). Adaptation processes in agriculture vs. market requirements and sustainable development principles. J. Agribus. Rural Dev., 4(50), 455-463. http://dx.doi.org/10.17306/J.JARD.2018.00443

In 2012 , this ratio was on average $18.5 \%$ in Poland and $13 \%$ in the EU-27; in the United Kingdom and Austria, it was $9.2 \%$ and $10 \%$, respectively (Grzega, 2015). In subsequent years, this share decreased, reaching $16.9 \%$ in Poland and $8.4 \%$ in the United Kingdom in 2015 (Statistisches Jahrbuch..., 2016). The figures above lead to an unambiguous conclusion that the role of agriculture in the national economy is decreasing.

One may ask, however, whether these ratios really testify to the decline in the importance of agriculture. The author believes they do not. Agriculture continues to be important, and remains the first irreplaceable link in the food economy, as well as a source of raw materials for the processing industry. In Western Europe, until the 1970s, the main function of agriculture was the production of food raw materials. More intensive production as well as technical and biological progress led to surpluses of food products in Europe (Majewski, 2002). As a result, the production function of agriculture ceased to be the primary one. Out of necessity, other agricultural functions, which had been underestimated or ignored before, were paid attention to. These were:

- landscape protection and landscaping,

- environmental protection,

- production of non-food products used in the processing industry,

- production of substrates for energy-generating purposes.
The fulfillment of the aforementioned agricultural functions is inseparably connected with land use management. Currently, rural areas account for over $90 \%$ of Polish territory and are inhabited by $38 \%$ of the Polish population. Agricultural land constitutes over $60 \%$ of rural areas. These areas are owned and used by farms which vary in size and nature and are the main or additional source of incomes for the farming families. Their income is heavily affected by processes taking place in the national economy and in agriculture which, in turn, are related to development trends of labor costs in the national economy, agricultural input prices and selling prices of agricultural produce. These trends are presented in Figure 1. The aforementioned processes are determined by:

- The continuous and constant increase in income of non-agricultural employees. This trend is observed in all countries with a market economy. In Poland, in 1995-2016, labor costs (composed mainly of salaries and wages) in non-agricultural sectors increased almost six times (5.76).

- At the same time, there was an over three-fold increase in the costs of agricultural inputs (3.19).

- At the same time, prices of agricultural products sold by farmers more than doubled (2.12) (Ziętara, 2017). These trends lead to a decrease in the unit profitability of products manufactured and sold by farmers, and thus to a decline in farming families' incomes. A farmer

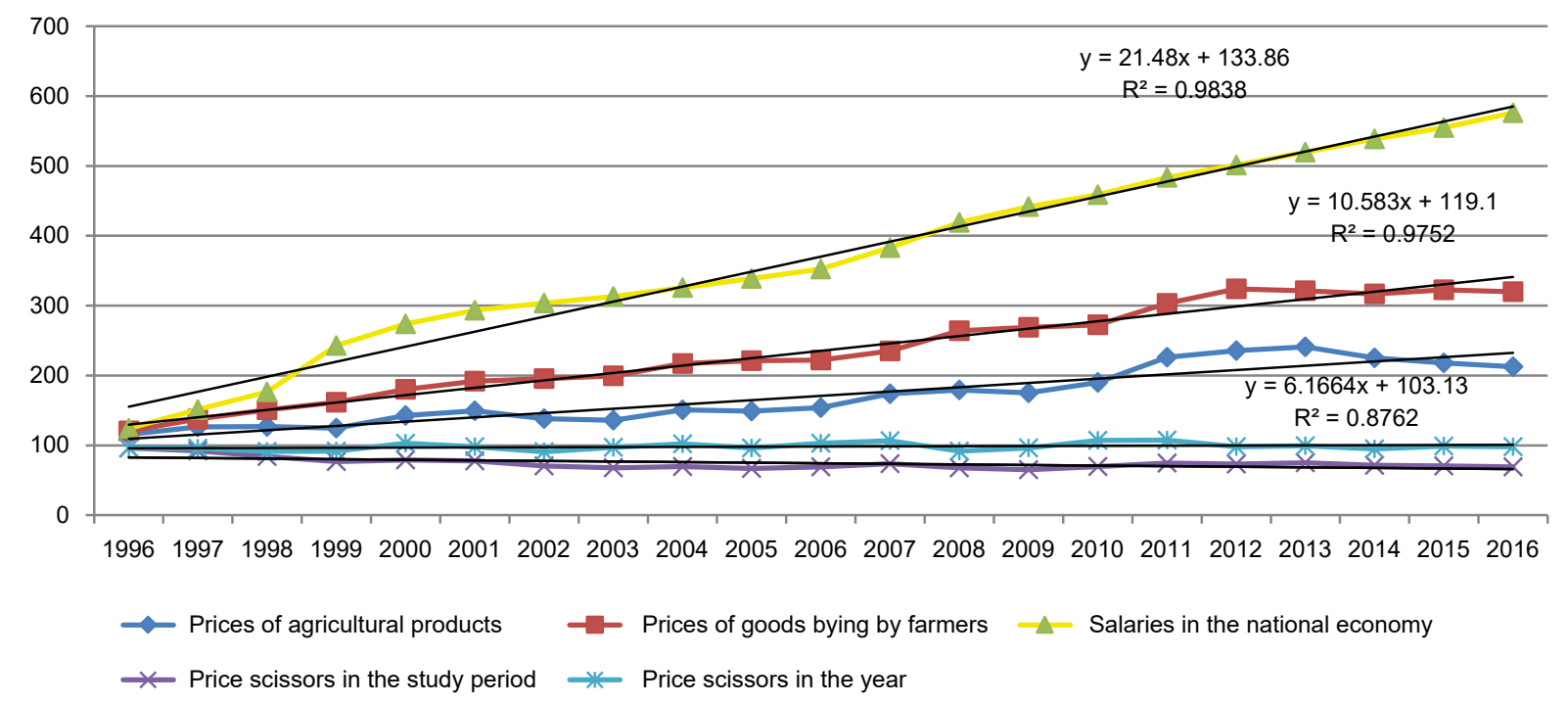

Fig. 1. Trends in labor costs, agricultural input prices and selling prices of agricultural products in 1995-2016 Source: Roczniki Statystyczne..., 1996-2017. 
wishing to generate satisfactory income has to increase workforce productivity. Given the limited demand for agricultural products observed in Poland, the process of increasing workforce productivity in agriculture (especially in family farms) is bound to make some farmers discontinue their farming activity, so that others may increase workforce productivity, mainly by increasing their farm area. This thesis can be illustrated by the following facts: in 1990, a farmer running a farm with an area of 10 ha of UAA composed of class IV soil was able to earn incomes at a level equal to the average recorded in non-agricultural sectors of the economy. In subsequent years, the area needed to achieve that level increased to 15,20 and 30 ha, to be currently in the range of 30-50 ha of UAA (Ziętara, 2012; 2017). The rate of outflow of the agricultural population to non-agricultural sectors depends on the economic development of a country. In countries with a robust market economy, such as Denmark, the Netherlands, the United Kingdom and the US, where the level of employment in agriculture matches the production volume, farmers generate incomes equal to the average recorded in non-agricultural sectors of the economy (Statistisches Jahrbuch..., 2016).

Given the conditions prevailing in Poland and the current level of economic development, non-agricultural sectors are unable to fully absorb the agricultural workforce. As a result, the number of farms, and thus their average area, has not changed significantly in the entire post-war period or in the last ten to twenty years. However, there has been significant polarization of farms. At one extreme, there are small farms with an area of up to 5 ha of UAA, accounting for $55 \%$ and $53 \%$ of the total number of farms with an area of at least 1 ha of UAA in 1996 and 2016, respectively. The aforementioned numbers correspond to the structure of farms grouped by economic size expressed as $\mathrm{SO}^{1}$ in EUR thousand. In 2016, the share of very small farms (generating an SO of up to EUR 8,000) was 66\% (GUS, 2017). At the other extreme, the share of farms with an area of 20 ha of UAA or more increased over this period from $4.33 \%$ to $9.80 \%$, while the share of farms in the range of 5-20 ha of UAA decreased from $40 \%$ to $37 \%$ (Rocznik Statystyczny Rolnictwa, 2001; GUS, 2017). Small farms, except for specialized ones, are referred

${ }^{1}$ SO: Standard Output calculated as the average output in a five-year period, expressed in EUR thousand. to as auxiliary farms ${ }^{2}$, run mainly for the farmer's own needs, that have no or very limited contact with the market. It is estimated that over $50 \%$ of farms with an area of 1-5 ha do not enter the market at all. These farms are run extensively, and have the greatest proportion of land lying fallow. The introduction of direct payments after Poland's accession to the European Union resulted in a partial elimination of fallows, but these farms continue to be very extensive. The other group of farms, with an area of 20 ha or more, are commercial farms. They use over $50 \%$ of UAA, and their share in commercial production exceeds $60 \%$ (Rocznik Statystyczny Rolnictwa, 2016). Most of these farms are characterized by a high level of production intensity. The dual nature of Polish agriculture is also emphasized by Wigier (2013).

Farm polarization is very strongly related to the management of rural production space. According to Prof. E. Reisch from the University of Hohenheim, there are two approaches to rural development (Reisch, 2002). The first one provides that agriculture and forestry play an important role in rural development. Therefore, farmers are obliged to come up with solutions, including the rationale behind the opportunities to generate income outside agriculture, e.g. through agritourism, horse riding, fishing, etc. It is important to use natural resources and to deal with overcapacity of machinery and equipment by providing services which help farmers increase their income.

According to the other approach, an important role in rural development should be played by policies and social management, which need to be enhanced in regions with poor agriculture and low production capacity in terms of technical infrastructure. It is vital to construct roads and transport links which should stimulate rural development through multilateral exchange of goods and services between individuals, enterprises and institutions, to make rural areas rich in capital, technologies and incomes.

The author believes Poland should use both approaches at the same time. Rural development is fostered by multifunctional agriculture, which means that on top of production functions, farms should also provide "green" (environmental) services, mainly in the

\footnotetext{
${ }^{2}$ This term refers to farms in which the share of farming incomes in the total farming family's income is less than $50 \%$, and in which the farmer contributes less than $50 \%$ to total labor inputs.
} 
Ziętara, W. (2018). Adaptation processes in agriculture vs. market requirements and sustainable development principles. J. Agribus. Rural Dev., 4(50), 455-463. http://dx.doi.org/10.17306/J.JARD.2018.00443

area of landscape protection. But how can these functions be actually performed by different groups of farms, namely auxiliary farms and highly commercial ones? As for the group of highly commercial farms, it is certainly preferable to operate in accordance with the principles of sustainable development, to ensure that standards conducive to the preservation of environmental goods are respected. In addition to production functions, these farms are capable of providing green services. They rely on various farming systems: conventional, organic, integrated and precision farming (differing in the degree of compliance with sustainable development principles). In spite of extensive production, the other group (auxiliary farms) do not always operate in accordance with standards conducive to the abovementioned principles of sustainable development. As these farms have a small area and lack adequate equipment, they have limited capacity to provide green services for the benefit of the environment (Józwiak et al., 2018). In order to fulfill their function, they must have adequate organization and enough land. It is necessary to merge them to eliminate onerous checkerboarding and ensure proper organization of the farms' production space.

More generally, it is reasonable to claim that in a developed market economy, agriculture has and will have a permanent place, and its role is and will be significant, despite its decreasing share in GDP and employment. The special role of agriculture will be related to land use management in rural areas. Therefore, it is necessary to evaluate various farming systems in terms of their compliance with sustainable development principles.

\section{PURPOSE OF THE STUDY, METHODS AND SOURCES}

The key purpose of this study is to assess farming systems in terms of their compliance with the sustainable development principles ${ }^{3}$. The most common farming systems will be evaluated: conventional, organic, integrated and precision farming. The research materials

${ }^{3}$ The Polish literature uses two terms: "zrównoważony rozwój" and "trwały rozwój", meaning "sustainable development" in English. Both Polish terms have a similar meaning, but the author believes that "trwały rozwój" better matches social expectations with respect to agriculture. More in (Majewski, 2008). In the Polish version of this paper, the term "trwały rozwój" was used. include statistical data and literature on the subject as well as the rules of the Common Agricultural Policy. The study was carried out using a descriptive and comparative method with data presented in tables.

\section{PREVIOUS TRENDS IN AGRICULTURAL DEVELOPMENT IN THE CONTEXT OF THE COMMON AGRICULTURAL POLICY}

The development of European agriculture in the postwar period, beginning with the 1957 Treaty of Rome, was determined by the Common Agricultural Policy (CAP) implemented by the European Economic Community (EEC), and - from November 11, 1993 - by the European Union (EU) established by the Maastricht Treaty. This policy has evolved under the influence of changes taking place in the European and global economy as well as in the political situation. It comprises several characteristic stages, such as:

- 1958-1968: stimulating growth in agri-food production in order to achieve food self-sufficiency,

- 1968-1993: limiting the production scale and volume by means of market categories for the implementation of structural mechanisms,

- 1993-2000: liberalization of agricultural subsidies and reduction of protectionism,

- 2000-2007: stimulating increased competitiveness of the EU food sector and reducing the intensity of agriculture,

- 2007-2013: transformation of the CAP into the Common Agricultural and Rural Policy (CARPE).

- 2014-2020: rural development through fostering knowledge; increasing agricultural profitability and competitiveness; supporting the organization of supply chains; animal welfare and risk management; low-emission economy; restoring ecosystems and supporting social inclusion,

- lines of change after 2020: sustainable market orientation of agriculture; accounting for environmental protection requirements; mitigating the effects of climatic change and ensuring rural vitality.

The aforementioned stages of the CAP clearly indicate the lines of change. In the first period (1958-1968), economic and social objectives prevailed. The economic objectives were related to ensuring food security (stabilization of supply and demand) through increasing agricultural productivity owing to technical and biological progress. The social objectives were related to 
ensuring adequate income for farmers and stable, reasonably priced food supplies for customers. The implementation of the above objectives was supported by the state budget.

The implementation of the objectives in the first period led to food overproduction and environmental burdens. Therefore, in the second period, it was necessary to adjust the CAP to limit the production scale. Political factors, mainly the influence of the International Trade Organization (GAAT and WTO), also had a significant impact on the change to the CAP, as they demanded reducing the budget support for agriculture, claiming that it distorted international competition. During this period, a number of interventions were introduced, which were well reflected in the Mansholt Plan, providing for structural changes leading to a reduction in the number of farms and an increase in their economic strength.

Starting from the third period (1993), CAP objectives evolved towards changing the methods of agricultural support. Support for production and farmers' income was gradually abandoned to be replaced by payments allocated under measures taken to protect the environment, climate and development of rural areas. This line of evolution in the CAP is highly likely to be continued after 2020. It is therefore necessary to determine whether and to what extent farms using different farming systems will be able to implement the aforementioned CAP objectives.

\section{FARMING SYSTEMS}

A farming system is a way of managing agricultural space as regards crop and animal production and processing, measured based on ecological and economic criteria (Niewiadomski, 1993). Using the degree of agriculture's dependence on industrial inputs and opportunities to pursue sustainable development as a criterion, the following farming systems were identified: conventional, organic, integrated and precision farming.

\section{CONVENTIONAL FARMING SYSTEM}

According to the Institute of Soil Science and Plant Cultivation, "conventional farming is a system aimed at maximizing profits through high plant and animal yields. Specialized farms achieve this by using production technologies based on a high consumption of productive inputs and a low consumption of labor inputs" (FijolAdach, 2016). This definition is debatable, as it equates this system to intensive farming using industrial inputs. A more accurate definition of the conventional system was given by Z. Wójcicki who identifies the following subsystems: traditional (historical, extensive) systems, multi-line plant and animal production systems (medium intensive) and specialist farming systems (intensive) (Wójcicki, 2008). Generally, the conventional farming system includes various traditional methods of farming, differing in production intensity, degree of care for the natural environment and compliance with good agricultural practice. Nowadays, in highly developed countries (US, Belgium, Denmark, the Netherlands and Germany), conventional agriculture is a synonym for highly intensive, modern farming systems (Majewski, 2008). In Poland, given the dual nature of agriculture, it can be assumed that the conventional system includes both medium- and highly-intensive commercial farms as well as small, poorly or non-commercial extensive farms. In Poland, the conventional (intensive and extensive) farming system prevails. In 2016, its share in total utilized agricultural area was about $96 \%{ }^{4}$.

\section{ORGANIC FARMING SYSTEM}

According to Runowski, organic farming is "a farming system with sustainable crop and animal production on the farm, based on inputs of biological and mineral origin that have not been technologically processed" (Runowski, 1996). This means that no chemical crop protection agents or synthetic fertilizers are used in the organic farming system. Organic farming has a long tradition, dating back to the early $20^{\text {th }}$ century in Western Europe and the USA. It developed more intensively in the second half of the $20^{\text {th }}$ century and was related to economic development of countries and increased ecological awareness of societies. In Poland, the development of organic farming started after the political and economic transformation in 1989, particularly after Poland's accession to the European Union in 2004. The increase in the number of certified organic farms continued until 2013 when 19,872 farms were registered. In subsequent years, the number of organic farms decreased to 17,688

\footnotetext{
${ }^{4}$ Total UAA less areas used by organic farms $(3.68 \%)$ and farms under an integrated system $(0.19 \%)$ (Rocznik Statystyczny Rolnictwa, 2017)
} 
(by $11 \%$ ). The number of organic farms in the conversion period reached a maximum of 7,681 in 2010 , to decrease to 4,746 (by $38 \%$ ) in 2016 . The area under certified organic crops would increase until 2015, reaching a maximum of 501,925 ha. In 2016 , it decreased to 430,896 ha (by $14 \%$ ). The maximum area of organic crops in the conversion period was recorded in 2010 when it reached 210,974 ha. By 2016, it was reduced by $50 \%$, and the share of areas under organic crops (certified or in the conversion period) in the total area of UAA was $3.68 \%$. It is difficult to clearly determine the lines of further development of organic farms. Experiences in other countries show that once a certain area of organic crops has been reached, it does not increase afterwards. Furthermore, it can be observed that organic farms do not fully comply with the principle of sustainable plant and animal production. According to the Agricultural and Food Quality Inspectorate, in 2016, 83.2\% of the total number of 22,435 organic farms were engaged in crop production only. The remaining $16.8 \%$ of organic farms were engaged in mixed crop and animal production. In 2015, these figures were as follows: $81.2 \%$ and $18.8 \%$, respectively (Raport..., 2017). This is partially because organic farming support was allocated to crop production only (Rozporządzenie..., 2017). It is highly likely that this farming system will remain a niche and will not play a significant role in the implementation of sustainable agricultural development principles.

\section{INTEGRATED FARMING SYSTEM}

According to Majewski, the integrated farming system is "a farming method that enables meeting economic and ecological objectives through an informed use of self-regulating agroecosystem mechanisms and of modern production techniques; and through systematic improvements in farming and implementation of various forms of progress (mainly biological progress), in a manner conducive to the accomplishment of the system's objectives" (Majewski, 1996). In this farming system, unlike in organic farming, it is permitted to use industrial inputs (synthetic fertilizers, crop protection agents, growth regulators, etc.), yet in scientifically justified quantities and when appropriate. As regards crop production, the integrated system follows the principle of "plant nutrition," rather than "soil fertilization" used in the conventional system. The integrated farming system is based on a holistic approach to farming, and relies on scientific knowledge. To meet the ecological and economic objectives, it is necessary to take into account the environmental, social and economic constraints that affect the farm's situation. By complying with the adopted principles, the integrated farming system does not result in excessive environmental burdens. Despite the unquestionable advantages of the integrated farming system, it is not widely adopted in formal terms. In 2016, 9,116 farms declared to be covered by this system (including 4,207 certified ones), and their share in UAA was only $0.19 \%$ (Roczniki Statystyczne Rolnictwa, 2017).

\section{PRECISION FARMING SYSTEM}

"Precision farming is based on comprehensive technologies which make up a farming system that adapts all agrotechnical elements to changing conditions of crop fields" (Dominik, 2010). The system uses advanced technologies, including satellite technology, and takes into account diverse soil conditions and the condition of crops in particular parts of crop fields. By identifying soil fertility, its structure, the condition of crops and weed infestation, it is possible to precisely dose fertilizers and pesticides when required. In spite of being oriented at the accomplishment of economic objectives related to the economical and more effective use of chemical inputs, this system also ensures the achievement of environmental benefits (Majewski, 2008). The current scale of precision farming is insignificant due to high capital expenditure. The rapid increase in labor costs will change the cost ratio and will accelerate the adoption of this system, especially in larger farms.

\section{FARMING SYSTEMS AND PRINCIPLES OF CIRCULAR ECONOMY AND SUSTAINABLE AGRICULTURAL DEVELOPMENT}

Due to their characteristics, farming systems can be assessed by compliance with the principles of sustainable agricultural development and circular economy. The idea of circular economy shares similar foundations with the principles of sustainable agricultural development. These are the depletion of natural resources and the growing burden on the environment resulting from the uncontrolled intensive use of industrial inputs (synthetic fertilizers and chemical crop protection agents) 
in agriculture. The idea of circular economy was recognized by the European Commission and reflected in Agenda 2030 (The 2030 Agenda..., 2016). "A circular economy is a development strategy that provides for economic growth without increasing resource consumption, a thorough transformation of production chains and consumption habits, and a transformation of industrial systems at the systemic level. It is based on technological, social and organizational innovation" (Leśkiewicz, 2017). The principles of circular economy pertain particularly to agriculture and are similar to the principles of its sustainable development.

The conventional farming system prevails in the vast majority of farms which vary in production intensity levels and in compliance with sustainable development principles. Therefore, circular economy principles are unlikely to be complied with.

The organic farming system complies with the principles of sustainable agricultural development to the greatest extent and is the least burdensome for the environment. Due to the fact that it provides for full use of the farm's own natural resources, it does not burden the environment and is fully compliant with circular economy principles. The organic farming system is based on sustainable crop and animal production, using fodders produced on the farm and animal feces as natural fertilizers (manure, compost). However, it lays down very high ethical and knowledge requirements. Past experiences show that it is not free of threats related to unfair agricultural practices. Alongside the development of this farming system, the problem of "fake organic products" emerged. It is also debatable that the European Commission accepts organic crop farms. Despite their unquestionable advantages, it is rather unlikely that organic farming will become the primary farming system. Instead, it will remain a niche.

The integrated farming system allows for the fullest possible compliance with the principles of sustainable development and circular economy. By relying on scientific grounds, it enables full implementation of economic and environmental objectives. Rather than excluding the use of industrial inputs, it strictly adapts their use to plant and animal needs, and therefore does not lead to an excessive burden on the environment. It also takes into account the environmental constraints related to respecting the principles of crop rotation as well as the criteria of good agricultural practice (Kodeks..., 2004). It can be said that the integrated farming system is a way to ensure that the farm is run in a professional way. From a formal perspective, integrated farming is currently a small-scale system. In practice, commercial farms (especially highly-commercial ones) are largely professional and comply with the principles of integrated farming (whether intentionally or not). The precision farming system complies with the sustainable development principles to an even greater extent.

This can be confirmed by the following figures from 2016: in farms with up to 10 ha of UAA, the share of cereals in the sown area was in the range of $76-78.5 \%$, while in farms with 50-100 ha and beyond 100 ha of UAA, it was $64.4 \%$ and $62.3 \%$, respectively. According to the Code of Good Agricultural Practices, the acceptable share of cereals in the sown area cannot exceed $66 \%$. The share of legumes (Fabaceae), very desirable due to their ability to bind nitrogen from the air, was $0.6 \%$ in farms with up to 10 ha of UAA, while in farms with 50 ha of UAA and larger it was $1.22 \%$. The share of oilseed rape in farms with up to 10 ha of UAA was ca. $3 \%$, while in farms with 50-100 ha of UAA and 100 ha of UAA and larger, it was $9.6 \%$ and $16.4 \%$, respectively (GUS, 2017).

It should be emphasized that agricultural activity is essentially an investment. Expenditure incurred by farmers in a given period brings long-term effects. This applies, for example, to soil liming in order to maintain the proper soil $\mathrm{pH}$, and to natural fertilization and proper crop rotation to maintain an adequate content of organic matter in soil. Furthermore, over $90 \%$ of farms engaged in this type of farming are family farms (which take into account the interests of the farmer's successor and the farm's sustainability when making their production and investment decisions). Therefore, professional farmers run their farms in accordance with good agricultural practices which ensure not only maintaining but also increasing the current yielding capacity of crops and animals. Considering the environmental and climatic impacts of agriculture under the Common Agricultural Policy, the European Union introduced mechanisms aimed at reducing the adverse effects of agricultural activity (cross-compliance 2003) and greening (20142020). J. Krzyżanowski comments on the introduction of the cross-compliance as follows: "As their awareness grew, farmers sought not to pollute the environment and ensure farm animals' welfare by themselves instead of waiting for the introduction of 18 EU regulations." 
Ziętara, W. (2018). Adaptation processes in agriculture vs. market requirements and sustainable development principles. J. Agribus. Rural Dev., 4(50), 455-463. http://dx.doi.org/10.17306/J.JARD.2018.00443

Similar statements are made also with respect to the greening program: "Farmers protect the soil anyway because they diversify crops on their own, and the role of procedures for introducing different crops under the greening program is marginal" (Krzyżanowski, 2018). The above statements point to difficulties associated with the development of effective ways of influencing farmers under the CAP to make them implement environmental objectives on their farms. Experiences to date suggest that professional farmers are aware that farming in accordance with the principles of good agricultural practices which ensure environmental and climatic protection is beneficial to them, and thus no financial incentives are required.

\section{STATEMENTS AND CONCLUSIONS}

1. The decline in the share of agriculture in GDP, employment and food expenses does not testify to its marginalization.

2. Agriculture is responsible for the management of agricultural space $(60 \%)$ and the development of rural areas (which constitute about $90 \%$ of the Polish territory).

3. Additional functions performed by agriculture, such as landscape protection and landscaping, environmental protection, production of non-food goods used in the processing sector and production of substrates for energy-generating purposes, are also important.

4. Farms, as primary production entities, are influenced by market forces and trends in the formation of prices of inputs, labor costs in the national economy and selling prices of agricultural products. These factors make farmers increase their production scale, mainly by extending their farm area.

5. Polish agriculture has a dual nature manifested through the coexistence of two groups of farms: commercial farms, which are the main source of the farm family's income, and poorly or non-commercial auxiliary farms with a small area (up to 5 ha of UAA).

6. Currently, the conventional farming system prevails in agriculture, as it is practiced by more than $90 \%$ of farms at various levels of production intensity.

7. The organic farming system, in spite of ensuring compliance with the principles of sustainable development and circular economy, is a niche, and nothing suggests that its scale will increase.
8. Polish agriculture should be based on the integrated farming system. It is used to a large extent by commercial farms, being the main source of farm families' income. This system is characterized by a professional approach to farming.

9. While the precision farming system has a minimum environmental impact, its requires high capital expenditure, and will therefore be used by large highlycommercial farms.

10. Experiences to date suggest that professional farmers, regardless of financial incentives under the CAP, do pursue environmental objectives.

\section{SOURCE OF FINANCING}

Financial resources of the Program Wieloletni [Multiannual Program] implemented by the Institute of Agricultural and Food Economics - National Research Institute under research task No. 4601 „Wyzwania globalizacyjne a konkurencyjność krajowych gospodarstw i przedsiębiorstw rolnych" [Globalization challenges and competitiveness of national farms and agricultural enterprises].

\section{BIBLIOGRAPHY}

Dominik, A. (2010). System rolnictwa precyzyjnego [Precision farming system]. Radom: Centrum Doradztwa Rolniczego w Brwinowie, Oddział w Radomiu.

GUS (2017). Charakterystyka gospodarstw rolnych w 2016 r. [Characteristics of farms in 2016]. Warszawa: Główny Urząd Statystyczny.

Grzega, U. (2015). Dochód i konsumpcja w gospodarstwach domowych w Polsce i w Unii Europejskiej w latach 2004 i 2012 [Income and consumption in households in Poland and the European Union in 2004 and 2012]. Handel Wewn., 4, 124-134.

Fijoł-Adach, E. (2016). Systemy produkcji rolnej we współczesnym rolnictwie. IUNG. Pobrano z: http://iung.pl/SD/ images/materialy/Systemy\%20produkcji\%20rolnej.pdf

Jezierski, A., Leszczyńska, C. (2003). Historia gospodarcza Polski [Polish economic history]. Warszawa: Key-Text.

Józwiak, W., Mirkowska, Z., Ziętara, W. (2018). Gospodarstwa pomocnicze a wykorzystanie ziemi rolniczej [Auxiliary farms and the use of agricultural land]. Warszawa: IRWiR PAN.

Kluk, K. (1954). O rolnictwie, zbożach, łąkach, chmielnikach, winnicach i roślinach gospodarskich [About agriculture, 
Ziętara, W. (2018). Adaptation processes in agriculture vs. market requirements and sustainable development principles. J. Agribus. Rural Dev., 4(50), 455-463. http://dx.doi.org/10.17306/J.JARD.2018.00443

cereals, meadows, hop gardens, vineyards and farm plants]. Wrocław: Ossolineum.

Kodeks Dobrej Praktyki Rolniczej [Code of Good Agricultural Practice] (2004). Warszawa: Fundacja Programów Pomocy dla Rolnictwa, FAPA.

Krzyżanowski, J. (2018). Dywersyfikacja upraw jako środek ochrony gleby w krajach Unii Europejskiej - czy to właściwe rozwiązanie? [Crop diversification as a measure to protect soil in the European Union countries - is it the right solution?]. Maszynopis w Katedrze Ekonomiki Rolnictwa i Międzynarodowych Stosunków Gospodarczych SGGW w Warszawie.

Leśkiewicz, K. (2017). Produkcja żywności w gospodarce o zamkniętym obiegu - wybrane aspekty prawne [Food production in a circular economy - selected legal aspects]. Stud. Iurid. Lublin., XXVI, 1.

Majewski, E. (1996). Koncepcja systemu integrowanej produkcji rolniczej [The concept of the integrated farming system]. Zagad. Ekon. Roln., 6, 39-55.

Majewski, E. (2002). Ekonomiczno-organizacyjne uwarunkowania rozwoju Systemu Integrowanej Produkcji Rolniczej (SIPR) w Polsce [Economic and organizational constraints of the development of the Integrated Farming System in Poland]. Warszawa: Wyd. SGGW.

Majewski, E. (2008). Trwały rozwój i trwałe rolnictwo - teoria a praktyka gospodarstw rolniczych [Sustainable development and sustainable agriculture - the theory and practice]. Warszawa: Wyd. SGGW.

Manteuffel, R. (1984). Ekonomika i organizacja gospodarstwa rolniczego [Economics and organization of a farm]. Warszawa: PWRiL.

Niewiadomski, W. (1993). Rolnictwo jutra [Agriculture of tomorrow]. In: Materiały $\mathrm{z}$ sympozjum „Biologiczne środowisko uprawne a zagrożenia chorobowe roślin" [Materials used at the conference "Biological crop environment and plant health risks"] (pp. 9-23). Olsztyn, ART.

Raport o stanie rolnictwa ekologicznego w Polsce w latach 2015 i 2016 [Report on the organic farming condition in Poland in 2015 and 2016] (2017). Warszawa: IJHARS. Rtrieved from: https://www.teraz-srodowisko.pl/media/ pdf/aktualnosci/3861-raport-o-stanie-rolnictwa-ekologicznego-w-polsce-w-latach-2015-2016.pdf

Reisch, E. (2002). Ekonomika rolnictwa [Agricultural Economics]. In: Stan i kierunki rozwoju nauk ekonomiczno-rolniczych z uwzględnieniem procesów integracji z Unią Europejską i procesów globalizacji [The status and directions of the development of economic and agricultural sciences, taking into account processes of integration with the European Union and globalization processes]. Warszawa: Wyd. SGGW.

Rocznik Statystyczny Rolnictwa 2001 (Statistical Yearbook: Agriculture 2001) GUS, Warszawa.

Rocznik Statystyczny Rolnictwa 2017 [Statistical Yearbook: Agriculture 2017]. Warszawa: Główny Urząd Statystyczny.

Rocznik Statystyczny 1960 (1961). Warszawa: Główny Urząd Statystyczny.

Rozporządzenie MRiROW z 15 września 2017 r. zmieniające rozporządzenie w sprawie szczegółowych warunków i trybu przyznawania pomocy finansowej w ramach „Rolnictwo ekologiczne" objętego PROW 2014-2020. [Regulation of the Minister of Agriculture and Rural Development of 15 September 2017 amending the Regulation on the Detailed Conditions and Procedure for Granting Financial Aid for "Organic Farming" under Rural Development Program for 2014-2020]. Dz. U z 2017 r. poz. 1775. retrieved from: http://prawo.sejm.gov.pl/isap.nsf/DocDetails.xsp?id=WDU20170001775

Runowski, H. (1996). Ograniczenia i szanse rolnictwa ekologicznego [Limitations and opportunities of organic farming]. Warszawa: Wyd. SGGW.

Statistisches Jahrbuch über Ernährung Landwirtschafts und Forsten (2016). Münster: Landwirtschaftsverlag.

The 2030 Agenda for Sustainable Development (2016). Retrieved from: https:/ec.europa.eu/europeaid/policies/ european-development-policy/2030-agenda-sustainabledevelopment en

Wigier, M. (2013). Model rozwoju rolnictwa polskiego w świetle efektów realizacji WPR [Model of Polish agriculture development in the light of the effects of the implementation of the CAP]. ZER, 5, 22-41.

Wójcicki, Z. (2008). Systemy produkcji rolniczej w Polsce [Farming systems in Poland). Infr. Ekol. Teren. Wiej, 2, 27-37.

Ziętara, W. (2012). Pozycja konkurencyjna polskich gospodarstw rolnych $\mathrm{w}$ procesie integracji i globalizacji [Competitive position of Polish farms in the integration and globalization process]. J. Agribus. Rural Dev., 2(24), 297-308.

Ziętara, W. (2017). Pozycja konkurencyjna polskich gospodarstw rolnych z uwzględnieniem typów rolniczych [Competitive position of Polish farms taking into account agricultural types]. Rocz. Nauk. SERiA, XIX, 3. 